\title{
Preventive Measures of Cyberbullying on Adolescents in Indonesia: A Legal Analysis
}

\author{
Rofi Wahanisa* \\ Universitas Negeri Semarang, Indonesia \\ Rahmawati Prihastuty \\ Universitas Negeri Semarang, Indonesia \\ Muhammad Dzikirullah H. Noho \\ Universitas Hasyim Asy'ari Tebuireng, Indonesia
}

\begin{abstract}
The increasing internet penetration in Indonesia has provided adolescents to expose pornographic content advertently. It inevitably includes other adverse impacts like fraud and violence, which begin with cyberspace. Also, cyberbullies on the internet have become a serious concern on how the government has anticipated it to prevent more practices in this cross-border experience. This study aimed to address the causes and impacts of online-based media on adolescents with the following preventive measures to reduce increasing cases of cyberbullying in Indonesia. This study used legal research in assessing the issue by sourcing primary data from statutory regulations and secondary data from academic resources. This study showed that cyberbullying continues to become an annoying issue among children, adolescents, and adults. The existing regulations provide insufficient protection preventing these practices because it does not specifically regulate its types and forms at defining cyberbullying. It suggested introducing a more specific regulation that outlines cyberbullying in ensuring the protection amidst the more borderless communication to prevent more adverse impacts on victims.
\end{abstract}

KEYWORDS: Cyberbullying, Information and Technology Law, Child Protection.

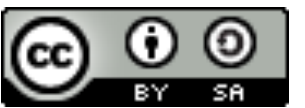

Copyright (C) 2021 by Author(s)

This work is licensed under a Creative Commons Attribution-ShareAlike 4.0 International License. All writings published in this journal are personal views of the authors and do not represent the views of this journal and the author's affiliated institutions.

\section{HOW TO CITE:}

Wahanisa, Rofi, et al., "Preventive Measures of Cyberbullying on Adolescents in Indonesia: A Legal Analysis"(2021) 8:2 Lentera Hukum 267-294. DOI: <https://doi.org/ 10.19184/ejlh.v8i2. 23503>.

Submitted: 09/03/2021 Reviewed: 22/05/2021 Revised: 16/06/2021 Accepted: 27/07/2021

\footnotetext{
* Corresponding author's e-mail: rofiwahanisa@mail.unnes.ac.id
} 


\section{INTRODUCTION}

In 2020, Indonesia's population reached 273 million, ${ }^{1}$ which put it as the largest country in Southeast Asia, ranked 5th in world population. ${ }^{2}$ The World Bank reported that more than half of the population, approximately $53,7 \%$, have accessed the internet, including social media. ${ }^{3}$ Consequently, internet penetration is relatively significant. On the other hand, there was a prevalent experience that students using technological devices at junior high school were inadvertently exposed to pornographic content. ${ }^{4}$ It asserts that smartphones could open access to pornographic content. Therefore, despite the benefits, the drawbacks are inevitable on accessing pornography. It includes other adverse impacts like fraud and violence, which begin with cyberspace.

In this context, the primary demographics of internet users in Indonesia were adolescents. According to the Indonesian Internet Providers Association (APJII), the age group of adolescents using the internet is increasingly growing, consisting of 12.5 million users at the age of 15-19 (late adolescent) and 765 thousand users at the age of 10-15 (early adolescent). ${ }^{5}$ A further study conducted by the Indonesian Ministry of Communication and Information Technology indicated that the majority of the respondents (80\%) used the internet to find data and information for school assignments or keep in touch with their friends through social media (70\%). ${ }^{6}$ Others used the internet to access music (65\%) or video (39\%)

1 Worldometers, "Indonesia Population", (2021), online: <https://www.worldometers. info/world-population/indonesia-population/>.

2 Belinda Yuen \& Leon Kong, "Climate change and urban planning in South East Asia” (2009) 2:3 Sapiens 1-11.

3 The World Bank, "Individuals using the Internet (\% of population) Indonesia|Data”, (2020), online: <https://data.worldbank.org/indicator/IT.NET. USER.ZS?locations=ID>.

4 Rachmaniar Rachmaniar, Puji Prihandini \& Preciosa Alnashava Janitra, "Perilaku Penggunaan Smartphone dan Akses Pornografi di Kalangan Remaja Perempuan" (2018) 7:1 J Komun Glob 1-11.

5 Masdum Ibrahim, "Relationship Internet Addiction With External Factors in Adolescent Age 15-18 Years At Senior High School Baleendah” (2019) 7:3 J Keperawatan Padjadjaran 255-265.

6 Gati Gayatri, et al., "Digital Citizenship Safety Among Children and Adolescents in Indonesia" (2015) 6:1 J Penelit dan Pengemb Komun dan Inform 1-16. 
sites. ${ }^{7}$ The findings concluded that $80 \%$ of children and adolescents use the internet, and most go online every day or once a week. ${ }^{8}$

Along with this more profound in using the internet, the bullying in cyberspace, commonly called cyberbullying, has increased. Cyberbullying is a new crime using technology that implies intimidation in which the suspects harass the victims through technological devices because the suspects want the victims harassed. There are many ways to attack the victims, such as through unpleasant messages and disturbing pictures to embarrass the victims. A study showed that $50 \%$ of 41 adolescents in Indonesia ranging from 13-15 have experienced cyberbullying, $84 \%$ of children aged 12-17 years old have experienced bullying, and most cases were cyberbullying. ${ }^{9}$ Cyberbullying includes publishing private data, cyberstalking (leading to real-world stalking), and acts of revenge by publishing photos or videos for intimidation and extortion..$^{10}$ Cyberbullying can have a psychological impact on the victims. In a study, it turned out that $37 \%$ of students say that cyberbullying has more impact on the victims. ${ }^{11}$ The effect hurts feelings and deteriorates one's self and psychological condition, leading to depression, sadness, and frustration.

One of the severe impacts caused by cyberbullying is the victims' tendency to attempt suicide. A study carried out by Patchin \& \& Hinduja revealead that $20 \%$ of the respondent have contemplated suicide, and all forms of bullying are significantly associated with the increased suicide attempts. ${ }^{12}$ These previous studies indicate the negative impacts of cyberbullying on adolescents. Regarding the rampant cases of cyberbullying in Indonesia and

7 Ibid.

8 Dewi Kartika Sari, Ido Prijana Hadi \& Asosiasi Pendidikan Tinggi Ilmu Komunikasi, Information and communication technology, dan literasi media digital cetakan pertama (Malang: Buku Litera, 2015).

9 Rahmat Syah \& Istiana Hermawati, "The Prevention Efforts on Cyberbullying Case for Indonesian Adolescent Social Media Users” (2018) 17:2 J Penelit Kesejaht Sos 131-146.

${ }^{10}$ Ibid.

${ }^{11}$ Ghada M Abaido, "Cyberbullying on social media platforms among university students in the United Arab Emirates" (2020) 25:1 Int J Adolesc Youth 407-420.

${ }_{12}$ Agustin Sukmawati \& Ayu Puput Budi Kumala, "Dampak Cyberbullying Pada Remaja" (2020) 1:1 Alauddin Sci J Nurs 55-65. 
adolescents' limited knowledge about this issue, preventive measures are urgently needed to prevent the negative impacts of cyberbullying on adolescents.

This study aimed to address the causes and impacts of online-based media on adolescents with the following preventive measures to reduce increasing cases of cyberbullying in Indonesia. This study comprises two main parts of the discussion. The first part examines the causes and impacts of cyberbullying in current adolescents. The second part analyzes measures to reduce adolescent cyberbullying cases, comprising self-prevention and preventive measures from parents, as per underlying existing legal issues.

\section{METHODS}

The method used was legal research, ${ }^{13}$ focusing on addressing problems in interpreting statutory regulations, given it is on human domination as an interpreter. ${ }^{14}$ This paper divided sources into primary and secondary data. The primary data focused on binding legal materials such as norms or basic rules. Meanwhile, secondary legal materials were legal materials that explain primary legal materials, including books, journal articles, academic papers, dictionaries, and web pages.

\section{CAUSES AND IMPACTS OF CYBERBULLYING ON THE CURRENT ADOLESCENTS}

\section{A. Causes of Cyberbullying on the Current Adolescents}

Early adolescence is a transitional period from childhood to adolescence. Adolescence is often regarded as a period in which individuals seek selfrecognition and self-identification by exploring and assessing their

${ }^{13}$ Dewi Rahmaningsih Nugroho \& Muhammad Dzikirullah H Noho, "Kajian Yuridis Kewenangan Pemerintah untuk Memerintahkan Melakukan Merger kepada Entitas Bank pada masa Wabah Covid19 dalam Rezim Perdagangan Internasional" (2020) 22:2 Maj Ilm Cakrawala 7-8.

${ }^{14}$ R Safa'at, "Ambivalensi Pendekatan Yuridis Normatif dan Yuridis Sosiologis dalam Menelaah Sistem Kearifan Lokal Masyarakat Adat dalam Pengelolaan Sumber Daya Alam” (2013) Lex Jurnalica. 
psychological characteristics to be accepted as a part of society. ${ }^{15}$ The internet can facilitate adolescents in adjusting themselves to the digital era as they can use the internet to learn, share information, and communicate. ${ }^{16}$ On the other hand, adolescents encounter serious problems related to the use of the internet. Many of them are addicted to online games, exposed to sexual materials, and involved in online betting or cyberstalking, experience violence, sexual harassment, and other types of cybercrime. ${ }^{17}$ One of the challenges adolescents face is that they are vulnerable to cyberbullying, either suspects or victims. ${ }^{18}$

To be sure, cyberspace is different from the real world that quickly facilitates adolescents in socializing and sending messages through internet services. It includes the way adolescents use social media to interact with others. In communication science, a person's interaction emerges on social media through applications of new technology devices such as the internet, smartphones, and computers. ${ }^{19}$ This process utilizes the media for specific purposes. ${ }^{20}$

Several studies reveal that heavy internet use and poor internet skills are the major causes of cyberbullying. ${ }^{21}$ Adolescents experience cyberbullying every day, so that they are likely to consider this as an ordinary phenomenon. Cyberbullying seems like a daily routine for both the suspects and victims-including when they talk to each other in school and go home

${ }^{15}$ Zahro Malihah \& Alfiasari, "Perilaku Cyberbullying pada Remaja dan Kaitannya dengan Kontrol Diri dan Komunikasi Orang Tua” (2018) 11:2 J Ilmu Kel dan Konsum 145-156.

${ }^{16}$ Desiana Risqi Hana \& Suwarti Suwarti, "Dampak Psikologis Peserta Didik yang Menjadi Korban Cyber Bullying” (2020) 1:11 Psisula Pros Berk Psikol 20-28.

${ }^{17}$ I Dewa Putu Eskasasnanda, "Causes and Effects of Online Video Game Playing among Junior-Senior High School Students in Malang East Java" (2017) 9:2 KOMUNITAS Int J Indones Soc Cult 191-202.

${ }^{18}$ Nelia Afriyeni, "Perundungan Maya (Cyber Bullying) Pada Remaja Awal"” (2017) 1:1 J Psikol Insight Dep Psikol 25-39.

${ }^{19}$ Ranny Rastati, "Bentuk Perundungan Siber Di Media Sosial Dan Pencegahannya Bagi Korban Dan Pelaku” (2016) 15:2 J Sosioteknologi 169-186.

${ }^{20}$ Rulli Nasrullah, "Perundungan Siber (Cyber Bullying) di Status Facebook Divisi Humas Mabes POLRI” (2015) 14:1 J Sosioteknologi 1-11.

${ }^{21}$ Qing Li, "Cyberbullying in high schools: A study of students' behaviors and beliefs about this new phenomenon” (2010) 19:4 J Aggress Maltreatment Trauma 372-392. 
and access the internet. The form is like Writing hurtful things through instant messages, text messages, or online games. Post insulting messages on social networking sites. Post or share embarrassing photos or videos Creating a fake profile to embarrass someone. ${ }^{22}$

Even though cyberbullying is not an ordinary phenomenon, cyberbullying is harsh treatment by a person or group of people, ${ }^{23}$ using the help of electronic devices that are repeated and continuous on a target who has difficulty defending himself. In other words, cyberbullying is intimidation by someone or more to corner, discredit others through the cyber world. ${ }^{24}$

Social media emerges as a result of advancements in information and communication technology. Social media invites everyone interested to participate by giving open feedback, giving comments, and sharing information quickly in unlimited time. Social media inevitably has a significant impact on someone's life. Someone can quickly gain popularity or conversely lose it. Social media, which is increasingly developing, enables information to spread out quickly in society. Any kind of information can be easily and quickly distributed to influence perspectives, lifestyle, and culture. People are invited to engage in dialogues and develop their logic and psychology on the screen through social media, representing direct human life. However, it is inevitable that messages broadcast via electronic media potentially direct people towards pro-social and anti-social behaviors. ${ }^{25}$

Facebook and Twitter have become the choices of the majority of social media users, especially adolescents, due to their diverse, interesting features offered. Approximately 53\% of the total Facebook users in Indonesia are

${ }^{22}$ Febrizal Antama, Mukhtar Zuhdy \& Heri Purwanto, "Faktor Penyebab Cyberbullying yang Dilakukan oleh Remaja di Kota Yogyakarta" (2020) 1:2 J Penegakan Huk dan Keadilan 182-202.

${ }^{23}$ Machsun Rifauddin, "Fenomena Cyberbullying pada Remaja (Studi Analisis Media Sosial Facebook)" (2016) 4:1 Khizanah Al-Hikmah J Ilmu Perpust Inf dan Kearsipan 35-44.

${ }^{24}$ Maulida Nur Mukhlishotin, "Cyberbullying perspektif Hukum Pidana Islam” (2018) 3:2 Al-Jinayah J Huk Pidana Islam 370-402.

${ }^{25}$ Wilga Secsio Ratsja Putri, Nunung Nurwati \& Meilanny Budiarti, "Pengaruh Media Sosial Terhadap Perilaku Remaja" (2016) 3:1 Pros Penelit dan Pengabdi Kpd Masy $47-51$. 
adolescents under 18 years old. A study carried out by Yahoo shows that the largest internet users in Indonesia are adolescents aging 15-19 years old (64.5\%). ${ }^{26}$ Based on a report by eMarketer, it is estimated that within 20112014 Indonesia will have the fourth largest social media users in the world with a total of 79.2 million users in 2014, significantly increasing from 34.4 million users in 2011. ${ }^{27}$ China remains to lead the proportion with 414.5 million users (2014), followed by the US with 170.7 million users (2014). ${ }^{28}$ Indonesia is the second country globally with the most considerable growth in social media users; while India recorded a growth of $51.7 \%$ this year, Indonesia increased by $51.6 \%{ }^{29}$ Simultaneously, China is the largest social media user, and it only achieves growth of $19.9 \% .{ }^{30}$

Social media provides adolescents convenience in interacting with the social environment and opportunities to learn not to be technologically illiterate. In addition, it can accelerate adolescents' maturity if it is used wisely, even if it may result in adverse impacts. For instance, social media users may be highly critical or demanding to each other or encourage harmful or antisocial behaviors. Communication through social media often creates problems leading to the court. It is a deliberate behavior carried out repeatedly to hurt others, making it difficult for the victims to defend themselves. Bullying can also be defined as an activity, or aggressive behavior deliberately carried out by a person or group of persons continuously from time to time against the victims who cannot defend themselves. It simply refers to systematic abuse of power. Its criteria of repetition, intention, and systematic power imbalance make bullying a form of unwanted aggression. Bullying can occur in many contexts, including the workplace, yet bullying in adolescence is the most studied issue. Bullying involves physical actions such as slapping or injuring and verbal actions such as insulting, teasing, cursing, and threatening. In this case,

\footnotetext{
${ }^{26}$ Lucy Pujasari Supratman, "Penggunaan Media Sosial oleh Digital Native" (2018) 15:1 J Ilmu Komun 47-60.

27 Ibid.

${ }^{28}$ Ibid.

${ }^{29}$ Ibid.

${ }^{30}$ Ibid.
} 
cyberbullying involves verbal actions-communication between interactants through written or oral modes. ${ }^{31}$

Cyberbullying is a term that refers to bullying behavior that occurs online such as online aggression, harassment, and aggression to attack individuals electronically. Cyberbullying is not a trivial issue. It often creates negative impacts on the victims. A survey in 2015 involving 2.731 adolescents from 13 to 15 years old revealed that $49 \%$ of the victims lost their confidence, $47 \%$ felt anxious, and 38\% tried to change themselves. ${ }^{32}$ At the same time, other data showed 30\% thought cyberbullying was a real-world disorder, $28 \%$ took revenge by sending something rude, 24\% did self-harm, 22\% changed their appearance to avoid harassment, $16 \%$ wanted revenge, and $13 \%$ stopped using social media or networking applications. ${ }^{33}$

Cyberbullying refers to bullying through instant messaging, e-mail, chat room, website, video games, or messages sent via cell phone. This bullying behavior arises and develops from various environmental factors. The factors include family, school, and peer group. Moreover, cyberbullying behavior can also be motivated by revenge, anger, or frustration. It can also be caused by the suspects' lack of positive activities while various technological facilities are widely available and easily accessible, leading to deviant behavior. It is assumed that the suspects are the victims of bullying in the real world who want revenge and express their anger. ${ }^{34}$

In the theory of the Male Phenomenon, men are more naughty than women. The main reason is that delinquency is considered a male nature, or the masculinity culture views that it is natural for men to be naughty. ${ }^{35}$ However, this is not entirely true because both men and women participate

${ }^{31}$ Ela Zain Zakiyah, Sahadi Humaedi \& Meilanny Budiarti Santoso, "Faktor Yang Mempengaruhi Remaja Dalam Melakukan Bullying” (2017) 4:2 Pros Penelit dan Pengabdi Kpd Masy 324-330.

${ }^{32}$ Manalu Rouli Alisah Lusi, "Studi Fenomenologis Memahami Pengalaman Cyberbullying Pada Remaja” (2018) 6:4 Interak Online 448-459.

${ }^{33}$ Ibid.

${ }^{34}$ Fasya Syifa Mutma, "Deskripsi Pemahaman Cyberbullying Di Media Sosial Pada Mahasiswa” (2019) 13:2 J Komun 165-182.

${ }^{35}$ Darman Manda \& Suardi, "Perempuan Maskulin” (2017) 3:1 Equilib J Pendidik 5766. 
in cyberbullying for different reasons. They also use different methods. Women tend to use a passive approach, such as spreading rumors about reputation and relationship breakdown. Meanwhile, men tend to use direct and cyber threats as a means of revenge. Furthermore, another view says that women often become the target of cyberbullying in their actions, while men tend to be the main suspect of violence in cyberspace.

The statement that women are more likely to be considered targets of cyberbullying is supported by some data. A survey was raised from the Application Poll (Jakpat) of 512 female respondents in Indonesia aged 1645 years. ${ }^{36}$ Around $12.52 \%$ of users stated that they had experienced verbal and visual harassment when accessing dating apps. ${ }^{37}$ The form of cyberbullying accepted by women is usually sexual content or pornographic images, sending profanity and being slandered by the perpetrator..$^{38}$

As for cyberbullying cases that occur in young girls in Indonesia, based on data from the National Commission for Women's Protection, cases of violence that occur online are dominated by cases of violence on social media. Most cyberbullying occurred via short messages, 235 on Facebook, $21 \%$ on Instagram, $21 \%$ on Twitter, and $10 \%$ on Snapchat. ${ }^{39}$ One of the most popular types of cyberbullying received by teenagers in Indonesia is the perpetrator sending abusive or vulgar tones. ${ }^{40}$ The most significant problem lies with teenagers who are reluctant to tell their parents about online incidents that have happened to them because they do not want their parents to limit their desire to use the internet. Cyberbullying in cyberspace does not only lead to women or men. Of course, in other words, cyberbullying does not recognize gender complicates preventive action. ${ }^{41}$

\footnotetext{
${ }^{36}$ Teguh Lesmana, "Hubungan Harga Diri dan Prasangka Gender Dengan Kecenderungan Perilaku Cyberbullying Pelajar Jakarta" (2020) 5:1 J Psikol TALENTA 45.

${ }^{37}$ Ibid.

${ }^{38}$ Raúl Navarro, "Gender Issues and Cyberbullying in Children and Adolescents: From Gender Differences to Gender Identity Measures" in Cyberbullying Globe (Cham: Springer International Publishing, 2016).

${ }^{39}$ Lesmana, supra note 36.

${ }^{40}$ Afriyeni, supra note 18.

${ }^{41}$ Mukhlishotin, supra note 24.
} 
The influence of the internet and social media has penetrated many areas. To be sure, it has positive and negative impacts, especially if the perpetrators are young people. Therefore, it is necessary to carry out socialization activities regarding the ethics of communicating to students at school to manage their social media accounts ethically. It is hoped that the use of social media for various purposes is very rapid among teenagers to positively contribute to the development of the creative industry in the country. Another fact reveals that democracy in every aspect of life in this modern era allows people to equalize rights between men and women. In this regard, the number of crimes committed by women is increasing dramatically. Based on the insight above, it is reasonable to argue that cyberbullying carried out by adolescents is not limited to gender because both men and women are potentially involved in the action, which is motivated by certain purposes.

Cyberbullying is carried out in diverse types and methods. It can be direct cyberbullying or indirect cyberbullying (by proxy). The former refers to bullying, which is carried out by sending direct messages to other adolescents targeted. The latter, on the contrary, is a type of bullying which uses another person to do cyberbullying on the targeted victims. The suspects can break into the victims' accounts, send uncomfortable messages, embarrass and abuse them, reset the password, and so on. Because of this action, the victims cannot access their accounts, lose their friends, feel embarrassed, and finally lose confidence. ${ }^{42}$

Other views regarding the classification used for cyberbullying behavior include flaming, harassment, denigration, impersonation, outing and tricking someone into revealing embarrassing secrets or information shared via the internet, exclusion, and cyberstalking. ${ }^{43}$ Specifically, the behaviors that students tend to use as perpetrators of cyberbullying are denigration

${ }^{42}$ Flourensia Sapty Rahayu, “Cyberbullying Sebagai Dampak Negatif Penggunaan Teknologi Informasi” (2012) 8:1 J Sist Inf 22-31.

${ }^{43}$ Sheira Ayu Indrayani \& Citra Aulia Johansari, "Cyberbullying Use on Teenage Artists and Its Implications on Increasing Awareness of Bullying" (2019) 18:2 Litera 275-296. 
(77.2\%), harassment (74\%), and flaming (70\%). ${ }^{44}$ While students who are victims of cyberbullying, the treatments that tend to experience denigration (79.2\%), flaming (78.7\%), and harassment (75.2\%). ${ }^{45}$

Cyberbullying should not only be directed at the victim's side but also at the perpetrator. A paper that researched the perpetrator by providing several respondents concluded that 16 respondents (21\%) abused their victims for the sole purpose of joking, and 13 respondents (17\%) were bullied because they wanted revenge. Simultaneously, five respondents (6\%) were bullied because of the physical and psychological characteristics of the victim, five respondents $(6 \%)$ were bullied on the internet because their identity was unknown, five respondents $(6 \%)$ were bullied because they were angry with the victim. Also, four respondents (5\%) were bullied because they wanted to entertain themselves, four respondents (5\%) were bullied in cyberspace because they did not meet the victim in person. ${ }^{46}$

Cyberbullying behavior motives arise from some aspects. First, revenge for bullying. By taking advantage of technological advances, the perpetrator takes bullying against others through social media. ${ }^{47}$ Second, the motivation to do cyberbullying is based on the fun so that it becomes a habit. ${ }^{48}$ Third, the behavior to imitate or act like someone else. ${ }^{49}$ Fourth, the desire to be respected is often detrimental to others, leading to cyberbullying behavior. Using social media and an identity that most people do not know makes it easier for someone to bully to achieve his desire. Fifth, cyberbullying based on personal desire. The perpetrator deliberately bullies without thinking about its consequences. ${ }^{50}$

${ }^{44}$ Endah Murwani, "Cyberbullying Behavior Patterns in Adolescents in Jakarta" (2019) 4:2 J Komun Ikat Sarj Komun Indones 96-103.

${ }^{45}$ Ibid.

${ }^{46}$ Afriyeni, supra note 18.

${ }^{47}$ Mira Marleni Pandie \& Ivan Th J Weismann, "Pengaruh Cyberbullying Di Media Sosial Terhadap Perilaku Reaktif Sebagai Pelaku Maupun Sebagai Korban Cyberbullying Pada Siswa Kristen SMP Nasional Makassar" (2016) 14:1 J Jaffray 4362.

${ }^{48}$ Ibid.

${ }^{49}$ Ibid.

${ }^{50}$ Ibid. 
The choice of cyberspace as a medium for bullying is because the assumption is only for jokes. Some parties think it is a joke, and some even think this is a serious matter until the victim is hurt and there is a desire to take revenge. The perpetrator's view of the impact of cyberbullying is almost the same as the victim's view. They assume that when someone becomes a victim of cyberbullying, they will feel sad, afraid, angry, anxious, and threatened by their bullying. However, some perpetrators think the victims feel happy because of the bullying they did. This assumption may arise may because they perceive their bullying as just a joke. ${ }^{51}$

Bullying and other anti-social behaviors share similar biological, personal, family, peer group, school/institution, and society. Several factors influence the suspects' motives in doing cyberbullying. The first is a family predictor. Bullying is closely related to family predictors such as insecure attachment, harsh physical discipline, and victim of overprotective parenting. ${ }^{52}$ Children or adolescents unconsciously project their inner discomfort (caused by family and home environment breakdown) into open conflicts or individual and mass confrontation. In other words, adolescents' tendency to provoke confrontation can be stimulated by poor household conditions. Harsh treatment and abuse by parents are likely to be risk factors influencing the bully or victim. In addition, family conditions that are troubled, chaotic, disorganized, arbitrary, uneducated, and less cherish humanity's value will automatically and unconsciously pass over bad habits and behaviors. As a result, children become arbitrary, wild, aggressive, and likely to use violence and cause confrontation in resolving problems..$^{53}$

The second is internal factors. The behavior which leads to crime is a failure in children's self-control system against their instinctive impulse. In other words, adolescents cannot control their instinct and primitive impulse and realize them into valuable and cultured actions. ${ }^{54}$ The third is external factors. External or exogenous factors are also known as environmental

${ }^{51}$ Afriyeni, supra note 18.

${ }^{52}$ Pandie \& Weismann, supra note 47.

${ }^{53}$ Cenceng, "Perilaku Kelekatan Pada Anak Usia Dini (Perspektif John Bowlby)" (2015) 17:2 Lentera 141-153.

${ }^{54}$ Abdul Sakban, et al., "Tindakan Bullying di Media Sosial dan Pencegahannya" (2018) 2:3 J Ilmu Sos dan Pendidik 205-214. 
influences, social factors, or sociological factors. They refer to stimuli and external influences leading to specific behaviors in adolescents (violence, crime, and mass confrontation). Peer groups and the school also generally have a significant impact in making students suspect of bullying.

\section{B. Impacts of Cyberbullying on Adolescents}

While bullying occurs in cyberspace, the victims can feel attacked everywhere, even in their own homes. There is seemingly no way out. It can have long-lasting impacts which influence the victims in many ways. They are mentally, ${ }^{55}$ emotionally, ${ }^{56}$ and physically. ${ }^{57}$ It has a long-term impact on the development of a person and even forms an attitude and mental maturity later. Victims of bullying will behave aggressively and easily commit acts of greatness even if not handled early, making adolescents take unexpected actions. The impact of cyberbullying in the early stages of the victim will feel uneasy and insecure about reducing concentration, especially in adolescents, which is very detrimental. The reason is that concentration in learning is vital. Thus, it will affect decreasing academic grades. Besides, cyberbullying can have a more severe negative impact on victims. They are social isolation, depression, self-harm, drug use, and teenagers can have suicidal ideas because they are not strong enough to experience the pressure they receive. ${ }^{58}$

The feeling of being laughed or harassed by others can lead to an unwillingness to communicate. Cyberbullying can even prompt suicide. However, this problem can be overcome, and the victims can also regain their confidence and recover their mental health. Given the magnitude of the danger caused by this incident, it is necessary to continue developing efforts to provide awareness to the public, mainly social media users, to use it wisely and adequately and anticipate all things that can harm and hurt

\footnotetext{
${ }_{55}$ The victims will feel annoyed, embarrassed, fooled, and even angry.

${ }^{56}$ The victims will feel embarrassed or lose interest in things they like.

${ }^{57}$ The victims will feel tired (lack of sleep) or experience such symptoms as stomachache and headaches.

${ }^{58}$ Retha Rizky Fitransyah \& Ema Waliyanti, "Perilaku Cyberbullying Dengan Media Instagram Pada Remaja Di Yogyakarta” (2018) 2:1 Indones J Nurs Pract 36-48.
} 
others. Spreading hatred, threats, and anger on social media is an act of violence with a broad and severe impact. Cyberbullying often feels superior and justifies the behavior he is doing towards the victim. ${ }^{59}$

The motive of someone doing cyberbullying is complicated to get rid of because it will cause branching problems. Attention to the perpetrators and victims of bullying is the responsibility of all parties. Because the perpetrators of cyberbullying include friends of victims and even people who are not known based on just wanting to joke, taking revenge with bullying in the real world make this problem, if not stopped as early as possible, drag on. Even perpetrators hide behind false guises on social media and commit cyberbullies against their friends, some of whom get personal satisfaction. From the victim's perspective, most of them are indifferent to the treatment they receive or even allow, and the worst part is that this reprisal is the cause of cyberbullying to take root.

Two current kinds of challenges make cyberbullying difficult to prevent. The first challenge is that many people do not consider the dangers or serious repercussions of cyberbullying. People perceive other forms of aggression or aggression that are more serious than cyberbullying. The second challenge relates to who is responsible for the abuse of technology, especially social media. ${ }^{60}$

Some of the perpetrators admitted that they did not know that what they had done was wrong. It is just for fun and does not mean anything, someone who does not know internet ethics can plunge himself into a cyberbully. ${ }^{61}$ Even though cyberbullying can have a psychological impact on victims who become depressed, people who experience cyberbullying can become depressed because they are constantly getting bad and negative messages that make them depressed and end up in a state of depression. The truth that cyberbullying can lead to death is because many victims end up committing suicide.

\footnotetext{
${ }^{59}$ Khusnul Aini \& Rista Apriana, "Dampak Cyberbullying Terhadap Depresi Pada Mahasiswa Prodi Ners" (2018) 6:2 J Keperawatan 91-97.

${ }^{60}$ Rahayu, supra note 42.

${ }^{61}$ Rastati, supra note 19.
} 


\section{MEASURES OF REDUCING CYBERBULLYING CASES ON ADOLESCENTS}

While everyone has the potential to practice cyberbullying, protection plays a pivotal role in avoiding it. Parents need to notice this issue because cyberbullying cases, on average, involve adolescents as either the suspect or victim. In other words, the aim is to prepare children as early as possible for the concept of sex and its forms of abuse, which are acts and words. Families and schools have an essential contribution in preventing harassment about sexuality. Sex-related information inevitably becomes more open as technology advances. It is better if sex education is taught appropriately and no longer thinks that sex education is a learning activity that is taboo to convey to children. ${ }^{62}$ The following measures can be applied to prevent cyberbullying.

\section{A. Self-prevention}

Many cases of cyberbullying today stem from the victim himself. Many things unwittingly place a person as a victim. In social interaction, communication ethics must be instilled in oneself. The ethics of communicating on social media guide thinking, acting, and behaving, referring to the rules of law and norms that apply in society and are expressed in actions and speech. ${ }^{63}$ The ethical principle to communicate is vital because young people use social media above their age, even though 18-21 years old are quite rampant to be the primary social media users. Unlike adults who can generally filter good or bad things from the internet, teenagers as internet users are just the opposite. Apart from not sorting out useful internet activities, they tend to be easily influenced by their social

\footnotetext{
${ }^{62}$ Indrayani \& Johansari, supra note 43. Lucky Nurhadiyanto, Chazizah Gusnita \& Tulus Yuniasih, "Analisis Cyber Bullying Berbasis Teknik Netralisasi (Techniques of Neutralization) Melalui Smartphone pada Pelajar SMA di Pesanggrahan , Jakarta” (2018) 2:1 J Kriminol 65-87.

${ }^{63}$ Rifauddin, supra note 23.
} 
environment without first considering the positive or negative effects of doing certain internet activities. ${ }^{64}$

While a person is known to be cyberbullying other people, it is essential to ensure that the perpetrator understands that he is doing is wrong. It is not uncommon for cyberbullies to feel that what they do will not affect the life of the person who is being hurt. It is consistent with the cockpit effect as described in the previous part. Perpetrators should also participate in faceto-face communication activities to restore empathy, such as hobby clubs, sports clubs, and hone skills. ${ }^{65}$

\section{B. Preventive Measures from Parents}

Because cyberbullying has severe impacts on adolescents, parents play an essential role in this condition. Family is the initial place for children to get an education. There are some preventive measures parents can take: ${ }^{66}$

\section{Providing safe internet education}

Giving education about safe social networks to children is the most fundamental step in preventing cyberbullying. Parents need to give an understanding of what children can and cannot do on social media. Parents also need to teach them how to manage privacy on each account. Parents also need to educate the posts that what children post cannot be truly deleted, so they need to be more selective in posting something.

${ }^{64}$ Muhammad Alam Akbar \& Prahastiwi Utari, "Cyberbullying Pada Media Sosial (Studi Analisis Isi Tentang Cyberbullying pada Remaja di Facebook)" (2015) $1 \mathrm{~J}$ Komun Massa 1-20.

${ }^{65}$ Rastati, supra note 19.

${ }^{66}$ Aan Eko Khusni Ubaidillah, "Peran Guru dalam Penanganan Peserta Didik yang Bermasalah dengan Perilaku Anti Sosial Cyberbullying” (2016) 6:2 Ta'dibia J Ilm Pendidik Agama Islam 17-24. 
2. Understanding the social media

Many social media, applications, and websites accessed by adolescents and parents can check what children most frequently access. Parents can further understand the policies applied by certain media, applications, or websites. They also need to understand how the users use the media and the age policy applied by the media.

\section{Monitoring online activities}

As parents, it is essential to frequently monitor online activities carried out by children by finding out with whom they are connected and what they do. In this case, parents need to approach children slowly so that they do not feel intimidated. In order to make it easier, parents can use similar social media to monitor the activities carried out by children in cyberspace so that parents can understand what children do.

Monitoring children's online activities by parents is very necessary, especially in today's era. Many supporting applications can carry out this monitoring. They are such as secure teen parental control. By using this application, children's activities can be monitored 24 hours. This application can track social networking sites, check web history, and control children's activities with their gadgets. Besides that, HomeTube, TimeAway, Kakatu, Kid Mode: Free Games + Lock, and many more applications can be optimized to monitor children's online activities.

\section{Educating to deal with cyberbullying}

Although children can do self-protection, educating them to deal with cyberbullying is worth trying. Some suggestions can be made, starting from not responding, ignoring, or blocking the bullying.

\section{Playing the role of a friend}

It is also helpful for parents to play the role of a friend for children. This may not directly prevent cyberbullying, but this way enables parents to 
understand children's lives. All the points mentioned can be easily understood as children will feel more comfortable sharing their privacy with friends than parents. Hence, playing the role of a friend will make children more comfortable, and the support given can be readily accepted. Apart from themselves being assisted by the participation of parents, third parties must participate in preventing cyberbullying. Because cyberbullying occurs in cyberspace through social media, companies that oversee social media must have a sense of responsibility for all user activities.

Social media providers have a big responsibility to prevent online bullying from occurring. The first steps are to provide educational tools and guides for children, parents, and teachers to learn about risks and ways to stay safe online and provide simple steps such as blocking, shutting down, and reporting cyberbullying. Apart from these companies in Indonesia, in particular, it has regulations related to online activities.

Through Law 11/2008, in conjunction with Law 19/2016 on Electronic Information and Transactions (ITE Law), cyberbullying is categorized into hate speech, although it is not very specific. However, at least there is a basis for reference to provide a deterrent effect on the perpetrators of bullying. Cyberbullying is a new form of crime based in cyberspace. There are still many countries that do not specifically regulate it. The enforcement of these rules is sometimes an extension of the interpretation of a regulation. Article 310(1) of the Criminal Code stated that a person who blasphemes in writing with no evidence of truth could be punished with a criminal offense of slander. Then, Article 310(2) states that a person who attacks others' honor or reputation in public is included in the classification of defamation.

The two articles are listed in Chapter XVI on Insult, with the concept being almost the same as cyberbullying done in cyberspace. Furthermore, bullying in other forms is considered intimidation. There is no use of the term intimidation from the Criminal Code, but acts related to bullying, one of which is persecution, can be seen in Article 351 of the Criminal 
Code. ${ }^{67}$ The Criminal Code requires a complaint mechanism for the initial prosecution. Article 319 states that prosecution can only be carried out based on a complaint from a victim. It is reiterated in Article 27(3) of the ITE Law reviewed in the Constitutional Court Decision Number 50/PUU-VI/2008 that confirms it an offense on the complaint. They will be legally sued when there are complaints from others. It becomes more arduous to prevent cyberbullying because the treatment tends to embarrass. Consequently, most victims keep it a secret compared to sharing it with others, even with their parents.

Open communication between parents and children is difficult to build when it does not start from the parents themselves. Generating respect, empathy, and paying attention to changes in children's behavior are needed to resolve the handling quickly. The ability of parents to understand changes in children's attitudes helps children open up problems that are being experienced. The characteristics of victims of cyberbullying are shown by passive behavior, which is a communication style that places the rights of others before placing personal rights and suppresses self-esteem or worthiness. The victims choose defensiveness to protect themselves from the threats they respond to in communication situations rather than understanding other's messages. The communication situation here is that the victim reacts to cyberbullying attacks, either in writing comments containing angry emotions towards one of the perpetrators or comments defending themselves by insulting the perpetrator who continues to insult the victim. ${ }^{68}$

By reducing the risk of surfing, the active role of all parties is paramount in providing supervision, guidance, and direction to use the internet positively. It is mainly for teenagers who are still looking for their identity to not fall into wrong associations. Sex education should be taught from an early age. Sex education is not about supporting children to have sexual

\footnotetext{
${ }^{67}$ Friskilla Clara S A T, Eko Soponyono \& AM Endah Sri Astuti, "Kebijakan Hukum Pidana Dalam Upaya Penanggulangan Cyberbullying Dalam Upaya Pembaharuan Hukum Pidana” (2016) 5:3 Diponegoro Law Rev 1-21.

${ }^{68}$ Akbar \& Utari, supra note 64.
} 
intercourse but explaining the natural function of sex as a part of themselves and the consequences of being abused. ${ }^{69}$

The Criminal Code regulates cyberbullying, such as defamation of someone's name to humiliate and insult another person. ${ }^{70}$ Emphasis on the final description above of the Criminal Code can only be applied in the real world, thus complicating the provisions of this article for the perpetrators of cyberbullying. In contrast to the opinion that the Criminal Code only covers problems in the real world, Mardjono Reksodiputro A criminologist Budi Suhariyantio stated that computer crime is actually not a new crime and is still within the scope of the Criminal Code to handle it. ${ }^{71}$ Regulations for dealing with computer crimes should be integrated into the Criminal Code and not a separate law. Emphasis on the final description above the Criminal Code can only be applied in the real world, making it more difficult to provide this article to the perpetrators of cyberbullying. The efforts of the Indonesian state to date are still in the stages of enacting the ITE Law to tackle cyberbullying based on hate speech. It is outlined in Article 27(3), ${ }^{72} 27(4),{ }^{73} 28(2),{ }^{74}$ and $29 .{ }^{75}$

Even though the four articles are still unable to cover all forms of cyberbullying that exist. Only focusing on actions that damage a person's good name and honor, the articles of the Criminal Code and the ITE Law are enacted. The freedom of opinion possessed by every citizen has

${ }^{69}$ Risa Fitri Ratnasari, "Pentingnya Pendidikan Seks untuk Anak Usia Dini” (2016) 2:2 J Tarbawi Khatulistiwa 55-59.

${ }_{70} \mathrm{~T}$, Soponyono \& Astuti, supra note 67.

${ }^{71}$ Budi Suhariyanto, Tindak Pidana Teknologi Informasi (Cybercrime); Urgensi Pengaturan dan Celah Hukumnya (Jakarta: Raja Grafindo Persada, 2014).

72 "Anyone knowingly and without right distributes and/or transmits and/or causes to be accessible Electronic Information and/or Electronic Documents that have contents of defamation and/or defamation."

73 "Anyone knowingly and without right distributes and/or transmits and/or causes to be accessible Electronic Information and/or Electronic Documents that have the contents of extortion and/or threats."

74 "Every person knowingly and without right distributes information aimed at creating hatred or enmity for certain individuals and/or community groups based on ethnicity, religion, race, and intergroup."

75 "Everyone knowingly and without authority sends Electronic Information and/or Electronic Documents that contain threats of violence or scare aimed personally." 
limitations, namely respect for human rights and peace in the community's social life. For this reason, there needs to be a study of children's behavior in their life, especially the use of social media, which cannot be denied as a child's communication culture today. The increasing number of cases of crime bullying committed by children today should get serious attention. ${ }^{76}$

Unlike some other countries in the world, it has regulated cyberbullying even further. For example, New Zealand with the Crimes Act 1961 as amended through the Harmful Digital Communications Act of 2015, France with the French Criminal Code in Articles 222-33-2, and the country of Canada with the Canadian Criminal Code with the title Offenses from statutory regulations with Code Number Bill C-13 on Protecting Canadians from Online Crime Act (protecting Canadians from online crime). ${ }^{77}$ Against person and reputation, these three countries pay attention to cyberbullying first. In the United States, Louisiana and North Carolina States have regulations related to cyberbullying. The 2011 Louisiana legislation on cyberbullying explains that cyberbullying transmits any textual electronic, visual, written, or oral communication with malicious intent and intentionally coerces, abuses, tortures, or intimidating a person under 18 years old. The North Carolina Article 60 ComputerRelated Crime Act states that cyberbullying is any person using a computer or computer network. ${ }^{78}$ With several countries that the Indonesian state can emulate, they can exchange ideas about the rules in these countries.

Consequently, the ITE Law can result in a legal vacuum regarding cyberbullying because it does not explicitly regulate the types and forms of cyberbullying. At least cyberbullying or cyberbullying has been categorized as a crime included in cybercrime as stipulated in Chapter VII concerning Prohibited Actions in Law No.11 of 2008 jo Law No.19/2016 concerning Electronic Information and Transactions. In the ITE Law, cyberbullying

\footnotetext{
${ }^{76}$ Jauhari Dewi Kusuma, "Penegakan Hukum Tindak Pidana Cyber Bullying Oleh Anak Berdasarkan Undang-Undang Nomor 11 Tahun 2008 tentang Informasi dan Transaksi Elektronik" (2018) 1:1 Unizar Law Review 1-16.

77 Wenggedes Frensh, et al., "Kebijakan Kriminal Penanggulangan Cyber Bullying Terhadap Anak Sebagai Korban” (2017) 5:2 Usu Law J 34-45.

${ }^{78}$ Ibid.
} 
actors can be charged under Articles 27(1), 27(3), 27(4), 28(2), and 29, as mentioned earlier.

The enforcement of cyberbullying cases is indeed quite complex. It fulfills the requirements of Articles 183 and 184 of the Criminal Procedure Code. The proof is a requirement to give confidence to the judge to issue a decision. Judges are prohibited from making their own decisions without being convicted of at least two existing valid pieces of evidence. With the enactment of the ITE Law, electronic evidence at the stage of an investigation, prosecution, and examination at court proceedings legally applies to any person who commits acts of Indonesian law or outside the Indonesian jurisdiction, which has consequences for Indonesian law and harms Indonesia's interests. ${ }^{79}$ The formulation of the ITE Law is flexible, and the law enforcement is carried out with the rule of interpretation. Indeed, the repressive laws have failed to fulfill the ideals of certainty, justice, and benefit for citizens.

\section{CONCLUSION}

Cyberbullying continues to become an annoying issue among children, adolescents, and adults. It is considered an act of intimidation, abuse, or deliberate harassment encountered by adolescents on the internet. Cyberbullying often does not receive special attention, and some parties even do not take it seriously. Cyberbullying causes severe threats to healthy development within school life. The suspects are likely to be involved in juvenile delinquency, crime, and alcohol abuse. The victims can also face long-term effects in which they potentially fall into depression and lose self-esteem. On the other hand, the existing regulations provide insufficient protection preventing these practices because it does not specifically regulate its types and forms at defining cyberbullying. It suggested introducing a more specific regulation that outlines cyberbullying in ensuring the protection amidst the more borderless communication to prevent more adverse impacts on victims.

${ }^{79}$ Mukhlishotin, supra note 24. 


\section{ACKNOWLEDGMENTS}

None.

\section{COMPETING INTEREST}

The authors declared that they have no competing interests.

\section{REFERENCES}

Abaido, Ghada M, "Cyberbullying on social media platforms among university students in the United Arab Emirates" (2020) 25:1 Int J Adolesc Youth 407-420.

Afriyeni, Nelia, "Perundungan Maya (Cyber Bullying) Pada Remaja Awa1"” (2017) 1:1 J Psikol Insight Dep Psikol 25-39.

Aini, Khusnul \& Rista Apriana, "Dampak Cyberbullying Terhadap Depresi Pada Mahasiswa Prodi Ners" (2018) 6:2 J Keperawatan 9197.

Akbar, Muhammad Alam \& Prahastiwi Utari, "Cyberbullying Pada Media Sosial (Studi Analisis Isi Tentang Cyberbullying pada Remaja di Facebook)" (2015) $1 \mathrm{~J}$ Komun Massa 1-20.

Alisah Lusi, Manalu Rouli, "Studi Fenomenologis Memahami Pengalaman Cyberbullying Pada Remaja” (2018) 6:4 Interak Online 448-459.

Antama, Febrizal, Mukhtar Zuhdy \& Heri Purwanto, "Faktor Penyebab Cyberbullying yang Dilakukan oleh Remaja di Kota Yogyakarta" (2020) 1:2 J Penegakan Huk dan Keadilan 182-202.

Borba, Michele, Membangun Kecerdasan Moral (Tujub Kebajikan Utama Agar Anak Bermoral Tinggi) (Jakarta: Gramedia Pustaka Utama, 2008). 
Cenceng, "Perilaku Kelekatan Pada Anak Usia Dini (Perspektif John Bowlby)" (2015) 17:2 Lentera 141-153.

Eskasasnanda, I Dewa Putu, "Causes and Effects of Online Video Game Playing among Junior-Senior High School Students in Malang East Java" (2017) 9:2 KOMUNITAS Int J Indones Soc Cult 191-202.

Fitransyah, Retha Rizky \& Ema Waliyanti, "Perilaku Cyberbullying Dengan Media Instagram Pada Remaja Di Yogyakarta" (2018) 2:1 Indones J Nurs Pract 36-48.

Frensh, Wenggedes, et al., "Kebijakan Kriminal Penanggulangan Cyber Bullying Terhadap Anak Sebagai Korban” (2017) 5:2 Usu Law J 3445.

Gayatri, Gati, et al., "Digital Citizenship Safety Among Children and Adolescents in Indonesia" (2015) 6:1 J Penelit dan Pengemb Komun dan Inform 1-16.

Gumbira, Seno Wibowo, Adi Sulistiyono \& Kukuh Tejomurti, "Menanggulangi Cyberbullying Di Sosial Media Dalam Perspektif Analisa Ekonomi Mikro" (2019) 48:4 Masal-Masal Huk 341-354.

Hana, Desiana Risqi \& Suwarti Suwarti, "Dampak Psikologis Peserta Didik yang Menjadi Korban Cyber Bullying" (2020) 1:11 Psisula Pros Berk Psikol 20-28.

Ibrahim, Masdum, "Relationship Internet Addiction With External Factors in Adolescent Age 15-18 Years At Senior High School Baleendah" (2019) 7:3 J Keperawatan Padjadjaran 255-265.

Indrayani, Sheira Ayu \& Citra Aulia Johansari, "Cyberbullying Use on Teenage Artists and Its Implications on Increasing Awareness of Bullying” (2019) 18:2 Litera 275-296.

Kusuma, Jauhari Dewi, "Penegakan Hukum Tindak Pidana Cyber Bullying Oleh Anak Berdasarkan Undang-Undang Nomor 11 Tahun 2008 tentang Informasi dan Transaksi Elektronik" (2018) 1:1 Unizar LawReview 1-16. 
Lesmana, Teguh, "Hubungan Harga Diri dan Prasangka Gender Dengan Kecenderungan Perilaku Cyberbullying Pelajar Jakarta” (2020) 5:1 J Psikol TALENTA 45.

Li, Qing, "Cyberbullying in high schools: A study of students' behaviors and beliefs about this new phenomenon" (2010) 19:4 J Aggress Maltreatment Trauma 372-392.

Malihah, Zahro \& Alfiasari, "Perilaku Cyberbullying pada Remaja dan Kaitannya dengan Kontrol Diri dan Komunikasi Orang Tua” (2018) 11:2 J Ilmu Kel dan Konsum 145-156.

Manda, Darman \& Suardi, "Perempuan Maskulin" (2017) 3:1 Equilib J Pendidik 57-66.

Mukhlishotin, Maulida Nur, "Cyberbullying perspektif Hukum Pidana Islam” (2018) 3:2 Al-Jinayah J Huk Pidana Islam 370-402.

Murwani, Endah, "Cyberbullying Behavior Patterns in Adolescents in Jakarta” (2019) 4:2 J Komun Ikat Sarj Komun Indones 96-103.

Mutma, Fasya Syifa, "Deskripsi Pemahaman Cyberbullying Di Media Sosial Pada Mahasiswa” (2019) 13:2 J Komun 165-182.

Nasrullah, Rulli, "Perundungan Siber (Cyber Bullying) di Status Facebook Divisi Humas Mabes POLRI” (2015) 14:1 J Sosioteknologi 1-11.

Navarro, Raúl, "Gender Issues and Cyberbullying in Children and Adolescents: From Gender Differences to Gender Identity Measures" in Cyberbullying Globe (Cham: Springer International Publishing, 2016).

Nugroho, Dewi Rahmaningsih \& Muhammad Dzikirullah H Noho, "Kajian Yuridis Kewenangan Pemerintah untuk Memerintahkan Melakukan Merger kepada Entitas Bank pada masa Wabah Covid19 dalam Rezim Perdagangan Internasional" (2020) 22:2 Maj Ilm Cakrawala 7-8.

Nurhadiyanto, Lucky, Chazizah Gusnita \& Tulus Yuniasih, "Analisis Cyber Bullying Berbasis Teknik Netralisasi (Techniques of 
Neutralization) Melalui Smartphone pada Pelajar SMA di Pesanggrahan , Jakarta” (2018) 2:1 J Kriminol 65-87.

Pandie, Mira Marleni \& Ivan Th J Weismann, "Pengaruh Cyberbullying Di Media Sosial Terhadap Perilaku Reaktif Sebagai Pelaku Maupun Sebagai Korban Cyberbullying Pada Siswa Kristen SMP Nasional Makassar" (2016) 14:1 J Jaffray 43-62.

Putri, Wilga Secsio Ratsja, Nunung Nurwati \& Meilanny Budiarti, "Pengaruh Media Sosial Terhadap Perilaku Remaja" (2016) 3:1 Pros Penelit dan Pengabdi Kpd Masy 47-51.

Rachmaniar, Rachmaniar, Puji Prihandini \& Preciosa Alnashava Janitra, "Perilaku Penggunaan Smartphone dan Akses Pornografi di Kalangan Remaja Perempuan” (2018) 7:1 J Komun Glob 1-11.

Rahayu, Flourensia Sapty, "Cyberbullying Sebagai Dampak Negatif Penggunaan Teknologi Informasi” (2012) 8:1 J Sist Inf 22-31.

Ranny Rastati, "Bentuk Perundungan Siber Di Media Sosial dan Pencegahannya Bagi Korban dan Pelaku” (2016) 15:2 J Sosioteknologi 169-186.

Ratnasari, Risa Fitri, "Pentingnya Pendidikan Seks untuk Anak Usia Dini” (2016) 2:2 J Tarbawi Khatulistiwa 55-59.

Rifauddin, Machsun, "Fenomena Cyberbullying pada Remaja (Studi Analisis Media Sosial Facebook)" (2016) 4:1 Khizanah Al-Hikmah J Ilmu Perpust Inf dan Kearsipan 35-44.

Safa'at, R, "Ambivalensi Pendekatan Yuridis Normatif dan Yuridis Sosiologis dalam Menelaah Sistem Kearifan Lokal Masyarakat Adat dalam Pengelolaan Sumber Daya Alam” (2013) Lex Jurnalica.

Sakban, Abdul, et al., "Tindakan Bullying di Media Sosial dan Pencegahannya" (2018) 2:3 J Ilmu Sos dan Pendidik 205-214.

Sari, Dewi Kartika, Ido Prijana Hadi \& Asosiasi Pendidikan Tinggi Ilmu Komunikasi, Information and communication technology, dan literasi media digital cetakan pertama (Malang: Buku Litera, 2015). 
Suhariyanto, Budi, Tindak Pidana Teknologi Informasi (Cybercrime); Urgensi Pengaturan dan Celah Hukumnya (Jakarta: Raja Grafindo Persada, 2014).

Sukmawati, Agustin \& Ayu Puput Budi Kumala, "Dampak Cyberbullying Pada Remaja” (2020) 1:1 Alauddin Sci J Nurs 55-65.

Supratman, Lucy Pujasari, "Penggunaan Media Sosial oleh Digital Native" (2018) 15:1 J Ilmu Komun 47-60.

Syah, Rahmat \& Istiana Hermawati, "The Prevention Efforts on Cyberbullying Case for Indonesian Adolescent Social Media Users” (2018) 17:2 J Penelit Kesejaht Sos 131-146.

The World Bank, "Individuals using the Internet (\% of population) Indonesia|Data”, (2020), online: <https://data.worldbank.org/ indicator/IT.NET.USER.ZS?locations=ID $>$.

T, Friskilla Clara S A, Eko Soponyono \& AM Endah Sri Astuti, "Kebijakan Hukum Pidana Dalam Upaya Penanggulangan Cyberbullying Dalam Upaya Pembaharuan Hukum Pidana" (2016) 5:3 Diponegoro Law Rev 1-21.

Ubaidillah, Aan Eko Khusni, "Peran Guru dalam Penanganan Peserta Didik yang Bermasalah dengan Perilaku Anti Sosial Cyberbullying" (2016) 6:2 Ta'dibia J Ilm Pendidik Agama Islam 17-24.

Worldometers, "Indonesia Population", (2021), online: <https://www. worldometers.info/world-population/indonesia-population/ >.

Yuen, Belinda \& Leon Kong, "Climate change and urban planning in South East Asia” (2009) 2:3 Sapiens 1-11.

Zakiyah, Ela Zain, Sahadi Humaedi \& Meilanny Budiarti Santoso, "Faktor Yang Mempengaruhi Remaja Dalam Melakukan Bullying" (2017) 4:2 Pros Penelit dan Pengabdi Kpd Masy 324-330. 
294 | Preventive Measures of Cyberbullying on Adolescents in Indonesia: A Legal Analysis

This page intentionally left blank 